The Cryosphere Discuss., https://doi.org/10.5194/tc-2017-176

Manuscript under review for journal The Cryosphere

Discussion started: 5 September 2017

(c) Author(s) 2017. CC BY 4.0 License.

\title{
Estimating interaction between surface water and groundwater in a permafrost region using heat tracing methods
}

\author{
Tanguang $\mathrm{GAO}^{1}$, Jie $\mathrm{LIU}^{2}$, Tingjun $\mathrm{ZHANG}{ }^{1 *}$, Yuantao $\mathrm{HU}^{1}$, Jianguo SHANG ${ }^{1}$, Shufa WANG ${ }^{1}$, \\ Xiongxin XIAO ${ }^{1}$, Chuankun LIU $^{2}$, Shichang KANG ${ }^{3,4}$, Mika SILLANPÄ̈̈ ${ }^{5,6}$, Yulan ZHANG ${ }^{3}$
} 5

${ }^{1}$ Key Laboratory of Western China's Environmental Systems (Ministry of Education), College of Earth and Environmental Sciences, Lanzhou University, Lanzhou, 730000, China

${ }^{2}$ Institute of Water Sciences, College of Engineering, Peking University, Beijing 100871, China

${ }^{3}$ State Key laboratory of cryospheric Science, Northwest Institute of Eco-Environment and Resources, Chinese Academy of

10 Sciences, Lanzhou 730000, China

${ }^{4}$ CAS Center for Excelence in Tibetan Plateau Earth Sciences, Chinese Academy of Sciences, Beijing 100101, China

${ }^{5}$ Laboratory of Green Chemistry, Lappeenranta University of Technology, Mikkeli, Finland

${ }^{6}$ Department of Civil and Environmental Engineering, Florida International University, Miami, Florida, USA

15 Correspondence to: Prof. Tingjun Zhang, e-mail: tjzhang @1zu.edu.cn

\begin{abstract}
Understanding the interactions between groundwater and surface water in permafrost regions is essential to the understanding of flood frequencies and river water quality of high latitude/altitude basins. The application of heat tracing methods, based on oscillating streambed temperature signals, is a promising geophysical method for identifying and quantifying the groundwater and surface water interactions. Analytical analysis based on one-dimensional convectiveconductive heat transport equation combined with the fiber-optic distributed temperature sensing measurements were applied on a streambed of a mountainous permafrost region in the Yeniugou basin of northern Tibetan Plateau. The results indicated that low connectivity between the stream and groundwater in permafrost and active layer. The interaction between surface water and groundwater increased with thawing of the active layer. This study demonstrates that heat tracing method can be applied to study surface water-groundwater interactions over temporal and spatial scales in permafrost regions.
\end{abstract}


The Cryosphere Discuss., https://doi.org/10.5194/tc-2017-176

Manuscript under review for journal The Cryosphere

Discussion started: 5 September 2017

(c) Author(s) 2017. CC BY 4.0 License.

\section{Introduction}

Permafrost, an integral part of Earth's cryosphere, has undergone unprecedented changes in the past few decades. Significant hydrological changes in permafrost regions have received worldwide attention because water resources and ecosystems are particularly vulnerable to climate change (Bense et al., 2012; Woo, 2012; Walvoord and Kurylyk, 2016). Due to its

5 hydrogeological function as an aquitard, permafrost impacts the movement, storage, and exchange of surface water (SW) and groundwater $(\mathrm{GW})$. Subsurface flow also influences the state of permafrost by enhancing heat transfer and accelerating thaw (Bense et al., 2009; Chasmer and Hopkinson, 2016). Under climate change, permafrost degradation will likely produce large changes in surface and subsurface hydrology concomitant with changes to the hydrological framework, particularly the SWGW exchange which correlates with water-heat exchange processes (Carey et al., 2013; Wellman et al., 2013; Kurylyk et al.,

10 2014). The SW-GW exchange directly reflects the effects of permafrost thaw on hydrological processes, such as subsurface flow paths, residence time, and the partitioning of water stored above and below ground. Therefore, understanding the interaction between hydrological changes and permafrost thaw is essential to reduce uncertainties in predicting the responses of water resources and aquatic ecosystems to climate change in high elevation regions (Cheng et al., 2014; Abbott and Jones, 2015).

15 Recently, Ye et al. (2009), Liu et al. (2011), Cuo et al. (2013), and Cheng and Jin (2013) investigated hydrological regimes in permafrost regions. Although explanations of the linkage between permafrost thaw and hydrological processes abound, the logistical challenges of measuring and monitoring subsurface water fluxes and storage in permafrost regions limits the predictions of how future climate change may influence hydrological conditions in these regions (Walvoord et al., 2012; Walvoord and Kurylyk, 2016). Furthermore, existing modeling studies of increases in baseflow and sub-permafrost flow are

20 based on hypothetical scenarios (Ge et al., 2011; Bense et al., 2012).

Heat tracing methods have been used to identify and quantify reach-specific SW-GW interactions in humid environments (Constantz et al., 2013; Irvine et al., 2017). Because of conduction and convection, heat is a naturally occurring tracer in stream systems, with daily temperature fluctuations within a SW body leading to temperature responses in the sediments at the SWGW interface (Constantz, 2008). By measuring streambed temperatures in an environment with significant differences in groundwater and surface water temperatures, the propagation of a heat signal by conduction and convection heat fluxes can be used as a proxy to indicate exchange flow directions or to quantify exchange fluxes (Hatch et al., 2006; Keery et al., 2007). With recent developments in measurement and logger technology, analytical approaches to interpret temporal and spatial dynamics of water fluxes from multilevel temperature records have received much attention and are now common practice (Rau et al., 2014).

30 In this study, we assess the feasibility of using heat tracing methods to estimate the SW-GW interactions in a discontinuous mountainous permafrost region of the northern Tibetan Plateau. We present a method to use heat as a tracer of SW-GW interactions which combines a one-dimensional convective-conductive heat transport equation with the temperature measurements by fiber-optic distributed temperature sensing method (FO-DTS). Since the SW-GW interactions in permafrost 
The Cryosphere Discuss., https://doi.org/10.5194/tc-2017-176

Manuscript under review for journal The Cryosphere

Discussion started: 5 September 2017

(c) Author(s) 2017. CC BY 4.0 License.

regions are generally different for river reaches in areas with and without permafrost, these regions present a good target for the heat tracing method. Therefore, this study will aim to (1) identify exchange flow patterns at the SW-GW interface in a mountainous permafrost region, and (2) test the validity of the heat tracing method in permafrost hydrology by comparing areas with and without permafrost. Our investigations will provide an essential display of the capability of heat tracing methods to estimate SW-GW interaction in permafrost environments.

\section{Methods}

\subsection{Study Area}

The hydrology in discontinuous permafrost regions is believed to be particularly sensitive to natural or human-induced climate changes, because of the potential flow exchanges between the water of suprapermafrost and intrapermafrost zones, or with

10 water in non-permafrost areas (Woo, 2012). The Yeniugou (YNG) Basin is located in the upper reaches of the Heihe River of the Qilian-Altun Mountain discontinuous permafrost region in the northern Tibetan Plateau (Fig. 1). It covers an area of approximately $5 \times 10^{3} \mathrm{~km}^{2}$ as a narrow basin stretching $160 \mathrm{~km}$ along the Heihe valley, with a width less than $60 \mathrm{~km}$. Elevations range from 2615 to $4876 \mathrm{~m}$ a.s.l., with a mean elevation gradient of $14 \mathrm{~m} \mathrm{~km}^{-1}$. Fifty-six small glaciers (with total area of $11.34 \mathrm{~km}^{2}$ ) are distributed at higher elevations (above $4500 \mathrm{~m}$ a.s.l.) on both sides of the Qilian Mountains (Huai et al., 2014).

15 Glacial meltwater contributes about $3.6 \%$ of the total river runoff (Cheng et al., 2014). The mountainous permafrost area occupies approximately $68 \%$ of the YNG basin according to the 1:4,000,000 Frozen Ground Map in China (Wang, 2006). Measurements from 18 boreholes drilled in the YNG basin show that the thickness of permafrost ranges from 0 to $113 \mathrm{~m}$ (Wang et al., 2013).

Atmospheric circulation patterns over the Tibetan Plateau are dominated by monsoons in summer and the Westerlies in winter

20 (Yao et al., 2012). Mean annual air temperature in the area is less than $2{ }^{\circ} \mathrm{C}$ and mean annual precipitation ranges from approximately $250 \mathrm{~mm}$ to $500 \mathrm{~mm}$ in the upper reaches of Heihe River (Gao et al., 2016). Snow-covered areas exceed $40 \%$ of the YNG basin in winter; however snow-covered days constitute less than $10 \%$ of the year, except on glaciers and perennially snow-covered areas (Bi et al., 2015).

\subsection{Heat tracing method}

25 The principle of the heat tracing method is that daily temperature fluctuations caused by solar radiation within a SW body lead to temperature responses (because of conduction and convection) in the sediments at the SW-GW interface (Constantz, 2008). However, temperature gradient measurements beneath the streambed combined with an analytical or numerical heat transfer model can only estimate point groundwater discharge (Rau et al., 2015). The application of distributed temperature sensors along river reaches can identify large spatial variations, significantly increasing the spatial and temporal scale of temperature

30 observations (Hatch et al., 2010; Krause et al., 2012; Selker et al., 2006), but this method cannot provide estimations of 
The Cryosphere Discuss., https://doi.org/10.5194/tc-2017-176

Manuscript under review for journal The Cryosphere

Discussion started: 5 September 2017

(c) Author(s) 2017. CC BY 4.0 License.

groundwater directly. In this study, we use an integrated approach that consists of distributed and gradient temperature measurements to investigate SW-GW interactions.

\subsubsection{One-dimensional heat transport equation}

The one-dimensional (1-D) convective-conductive heat transport equation (1-D HTE) has a sinusoidal temperature boundary

5 at the top and a constant temperature boundary at infinite depth. The streambed vertical fluxes are calculated by the extracted daily sinusoidal component of temperature (Rau et al., 2015). The one-dimensional heat convection conduction equation is (Eq. 1):

$\frac{\partial T}{\partial \mathrm{t}}=D \frac{\partial^{2} T}{\partial z^{2}}-v \frac{\partial T}{\partial \mathrm{z}}$

Where, $T$ is temperature, $t$ is time, $D$ is the effective thermal diffusivity, $z$ is depth, and $v$ is the thermal front velocity (Suzuki,

10 1960).

Stallman (1965) derived a solution for (Eq. 1) requiring two temperature time series recorded at different vertical positions, which allowed for the flow velocity from the damping of temperature amplitudes and phase shift. Following the development and expansion of that solution by Goto et al. (2005), Hatch et al. (2006), and Gordon et al. (2012), McCallum et al. (2012) extracted a system of equations that explicitly solved the thermal front velocity from consecutive pairs of temperature

15 amplitude and phase shift data. The thermal front velocity is defined as (Eq. 2):

$v=\frac{\Delta z\left(P^{2} L n^{2} A_{r}-4 \pi^{2} \Delta \Phi^{2}\right)}{\Delta \Phi \sqrt{\left(16 \pi^{2} \Delta \Phi^{4}+8 P^{2} \pi^{2} \Delta \Phi^{2} L n^{2} A_{r}+P^{4} L n^{4} A_{r}\right)}}$

Where, $v$ is the thermal front velocity $\left(\mathrm{m} \mathrm{d}^{-1}\right), \Delta z$ is the spacing between measurement points (m), $P$ is period (d), $A_{r}$ is the amplitude ratio, and $\Delta \Phi$ is the phase shift of temperature maxima $(d)$.

The direction of $v$ indicates gaining or losing conditions. Normally, to quantify the SW-GW interaction (Darcy velocity, $q$ ), it is by multiplying the estimated thermal front velocity $(v)$ with a constant $(\gamma$, Eq. 3):

$\gamma=\frac{n \rho_{w} c_{w}+(1-n) \rho_{s} c_{S}}{\rho_{w} c_{w}}$

Where, $\gamma$ is the Darcy velocity index, $n$ is porosity, $\rho_{w}$ and $c_{w}$ are the density $\left(\mathrm{kg} \mathrm{m}^{-3}\right)$ and heat capacity $\left(\mathrm{J} \mathrm{kg}^{-1}{ }^{\circ} \mathrm{C}^{-1}\right)$ of water respectively; $\rho_{s}$ and $c_{s}$ are the density $\left(\mathrm{kg} \mathrm{m}^{-3}\right)$ and heat capacity $\left(\mathrm{J} \mathrm{kg}^{-1}{ }^{\circ} \mathrm{C}^{-1}\right)$ of a solid.

The analytical solution of 1-D HTE is based on an assumption of steady state fluid flow (Stallman, 1965), which contrasts with the aim of understanding natural processes that are commonly transient in nature. Lautz (2012) and Rau et al. (2015) have shown that the quantification using heat tracing methods based on the assumption of harmonic temperature data can lead to potentially flawed flux estimates. Thus, we focused only on the direction and variation of the thermal front velocity $(v)$, rather than calculating the Darcy velocity $(q)$ and effective thermal diffusivity.

Since common signal-processing methods introduce erroneous temporal spreading of advective velocities and significant 30 anomalies (Rau et al., 2015), we developed a semi-automated computer program for deriving amplitudes and phases from the temperature data to delineate the noise signal in the temperature-time signal. The program selects the peak temperature and 
The Cryosphere Discuss., https://doi.org/10.5194/tc-2017-176

Manuscript under review for journal The Cryosphere

Discussion started: 5 September 2017

(c) Author(s) 2017. CC BY 4.0 License.

corresponding time in one temperature cycle based on daily fluctuations, followed by automatic selection of subsequent peaks and time across the remaining records. The program then selects the peaks and time in reverse, and uses the average of amplitudes and phases for the duplicate calculations.

\subsubsection{Fiber-optic distributed temperature sensing (FO-DTS)}

5 The pioneering of a vertical high-resolution DTS system for hydrologic applications was presented by Selker et al. (2006), which has been widely used in observing a broad range of hydrologic processes (Tyler et al., 2009; Liu et al., 2016). FO-DTS temperature measurement is based on the analysis of the temperature dependent Raman spectra backscatter properties of a laser pulse that is applied to, and propagates through, a fiber-optic cable (Selker et al., 2006). The backscattered light is spread across a range of wavelengths, some of which are affected by temperature changes while others are immune. This shift in the

10 light wavelength is referred to as the Raman effect; the light with wavelengths above the incident light is the Raman Stock signal and the light with wavelengths below the incident light is the Raman anti-Stokes signal. By very accurately measuring the difference in the signal intensity of the backscattered light, an accurate temperature measurement can be obtained.

Lauer et al. (2013) systematically investigated the capability to identify or estimate groundwater discharge from discharge points using FO-DTS and found that it was reliable when the contrast between groundwater and surface water temperatures

15 exceeded a certain threshold. The strength of the temperature anomaly (AT) were used as an indicator of the temporal variability of these signals, by comparing anomalies on different dates independent of general shifts in streambed temperature. It is described by the difference of a local temperature measurement to the spatial average temperature of the cable section within the streambed at a specific point (Eq. 4).

$A_{T}\left(X_{i}\right)=T\left(X_{i}\right)-\overline{\left(T_{(x)}\right)}$

20 Where, AT is strength of the temperature anomaly, $\mathrm{T}(\mathrm{x})$ is the temperature $\left({ }^{\circ} \mathrm{C}\right)$, and $\mathrm{Xi}$ is the measurement location along the cable.

The variability of $A_{T}$ is described by its temporal standard deviation (STDEV) (Eq. 5):

$\operatorname{STDEV}\left(A_{T}\left(X_{i}\right)\right)=\sqrt{\frac{1}{N} \sum_{t=1}^{N}\left(A_{V H G}\left(X_{i t}\right)-\overline{A_{V H G}\left(X_{l}\right)}\right)^{2}}$

Where, $X_{i t}$ is the measurement location at the time t.

\section{$25 \quad 2.3$ Field observation system}

We collected streambed temperature data from instruments hung in steel piezometers $(8 \mathrm{~cm}$ inner diameter) driven $80 \mathrm{~cm}$ below the base of streambed. A $0.5 \mathrm{~cm}$ diameter screen in the piezometer maintained the water fill and allowed for good thermal contact between the sensors and the streambed.

We installed four piezometers in areas with and without permafrost (S1 and S2 at seasonal frozen ground areas, P1 and P2 at 30 permafrost areas) approximately $1 \mathrm{~m}$ from the river bank and removed them after finishing the measurement (Fig. 1). We recorded the data at $15 \mathrm{~min}$ intervals with a $\mathrm{HOBO}^{\circledR}$ water temperature logger (Water Temp Pro v2, $\pm 0.21^{\circ} \mathrm{C}$ precision, Onset, 
The Cryosphere Discuss., https://doi.org/10.5194/tc-2017-176

Manuscript under review for journal The Cryosphere

Discussion started: 5 September 2017

(c) Author(s) 2017. CC BY 4.0 License.

Bourne, MA, USA) at 0, 20, and $50 \mathrm{~cm}$ depths from July to September 2015. We installed an automatic water level meter (Levelogger Model 3001 F2/M2, $\pm 0.1 \mathrm{~cm}$ precision, Solinst Canada Ltd., Ontario, Canada) near S1, and recorded water levels at $15 \mathrm{~min}$ intervals pressure gauge (Solinst Barologger, $\pm 0.05 \mathrm{kPa}$ precision).

We installed a $500 \mathrm{~m}$ ruggedized fiber-optic cable with two $50 \mu \mathrm{m}$ multimode fibers on the streambed approximately $1 \mathrm{~m}$ from

5 the river bank and secured the cable with approximately 100 tent pegs attached to the fiber-optic cable with plastic cable ties to avoid preferential heat conduction along the metal pegs. We anchored the cable to the streambed using cobbles.

The precision of fiber-optic temperature measurement is controlled by the total number of photons detected as a function of integration time and the spatial integration length (Rose et al., 2013). The applied FO-DTS system (AP Sensing, Böblingen, Germany) is capable of measuring temperature with high precision in $15 \mathrm{~min}$ intervals at a spatial resolution of $0.25 \mathrm{~m}$ using

10 couple-ended measurements.

To account for temperature offset and instrument drift, we placed a $30 \mathrm{~m}$ section of coiled cable and a built-in reference PT100 probe in an insulated box filled with water, using six hours for system maintenance and recalibration. We collected temperature data along the DTS cable continuously over a 48 h period (23-25 September 2015 at S1; 21-22 September 2015 at P2).

The precision of FO-DTS declines as signal strength decreases (Rose et al., 2013; Tyler et al., 2009). The calibration process

15 can be conducted automatically using the external temperature probe and the built-in program of the DTS equipment, which automatically calibrates the sensor cable in offset and enhanced in attenuation ratio. The calibrated temperature probe was in the same area as a specific length of the sensor cable (a reference loop) to obtain the exact temperature of this loop and to use this as the reference temperature. We collected double-ended measurements for the entire calibration period to offset signal loss along the length of the cable. The measurement precision of temperature after calibration was $\pm 0.12{ }^{\circ} \mathrm{C}$.

20 From 2012 to 2014, Gao et al. (2016) and Wang et al. (2013) established 18 monitoring boreholes installed a string of thermistors spaced at $0.5 \mathrm{~m}$ intervals record temperature in areas with and without permafrost in the YNG basin. The soil temperature was measured along depth profiles in boreholes from 0.5 to $10 \mathrm{~m}$ below the natural ground surface. The thermistors were made by the State Key Laboratory of Frozen Soil Engineering and provided an accuracy of $\pm 0.05{ }^{\circ} \mathrm{C}$. For this study, we chose three of these boreholes that were near the streambed temperature observation sites (S2, P1, and P2) and carried out insitu measurements manually two or three times on 18 June, 9-10 August, and 25-26 September in 2015.

Three automatic weather stations (Campbell USA; WS1, WS2, and WS3 in Fig. 1) recorded meteorological data at 30 min intervals at the nearby piezometers and boreholes; we also used a manual observation station (WS4, Fig. 1) belonging to the National Meteorological Network (elevation 3320 m a.s.l.).

\section{Results}

\section{3.1 Background temperature of streambed and permafrost}

The streambed temperature remains low in the YNG basin $\left(5-10{ }^{\circ} \mathrm{C}\right.$, Fig. 2). The streambed temperature varied from -2 to $22{ }^{\circ} \mathrm{C}$ during the observation period; diurnal oscillations ranged from 2 to $22{ }^{\circ} \mathrm{C}$. There existed a clear damping of the stream 
The Cryosphere Discuss., https://doi.org/10.5194/tc-2017-176

Manuscript under review for journal The Cryosphere

Discussion started: 5 September 2017

(c) Author(s) 2017. CC BY 4.0 License.

signal at S1, S2, P1, and P2, with the greatest damping at P2 and lesser damping at P1. The damping indicates the heterogeneous nature of the local physical and thermal properties.

In the streambed at $\mathrm{S} 1$, the temperature at the depth of $0 \mathrm{~cm}$ were the greatest with a mean value of $8.67{ }^{\circ} \mathrm{C}$, ranging from 0.01 to $22.3{ }^{\circ} \mathrm{C}$. P2 had the second largest range with a mean value of $7.79{ }^{\circ} \mathrm{C}$ with a range of $0.63-17.35{ }^{\circ} \mathrm{C}$. As expected, the

5 streambed temperature at P2 was lower than those at S2 and P1, because of its higher elevation and the thick permafrost. In the streambed at $\mathrm{P} 2$, the mean temperature at $0 \mathrm{~cm}$ was higher than that at $\mathrm{S} 2$ and $\mathrm{P} 1$, likely because of the shallower depth of the stream and the lower discharge. The mean temperature at the depth of $50 \mathrm{~cm}$ varied significantly across sites $\left(8.83{ }^{\circ} \mathrm{C}\right.$ at $\mathrm{S} 1,7.67^{\circ} \mathrm{C}$ at $\mathrm{S} 2,5.89^{\circ} \mathrm{C}$ at $\mathrm{P} 1$, and $5.39^{\circ} \mathrm{C}$ at $\mathrm{P} 2$ ) which is consistent with the elevation gradient between sites.

Figure 3 shows the soil temperature at depths of $0-10 \mathrm{~m}$ measured at sites near S2, P1, and P2. The temperatures show that S1

10 and S2 are at locations without permafrost, and P1 and P2 are at locations with warm permafrost $\left(\geq-1.5^{\circ} \mathrm{C}\right)$. We considered the depth of the $0{ }^{\circ} \mathrm{C}$ isotherm in late September as the active layer thickness (ALT), which is calculated by interpolating between closely measured points at the time of maximum thaw (Brown et al., 2000). Result showed that the ALT at P1 and $\mathrm{P} 2$ were $1.54 \mathrm{~m}$ and $2.78 \mathrm{~m}$, respectively.

\section{$15 \quad 3.2$ Temporal patterns of SW-GW interactions}

According to the1-D THE, the mean thermal velocities impacted on the difference of the physical and thermal parameters among the observation sites and varied from a maximum of $-3.12 \mathrm{~m} \mathrm{~d}^{-1}$ at $\mathrm{P} 1$, to a minimum of $-0.67 \mathrm{~m} \mathrm{~d}^{-1}$ at $\mathrm{P} 2$. The streambed at P1 is coarse grained, which could promote higher porosity and lower sediment density and heat capacities, while the other sites' streambed are relative fined. The negative thermal front velocities noted at all the sites indicate losing stream conditions

20 at all locations (with and without permafrost) during the soil thawing period (Fig. 4).

However, the temporal changes of thermal velocities showed a significant difference between the seasonal frozen ground areas and permafrost area. The trends of the thermal velocities at S1 and S2 were not significant, while results at P1 and P2 showed a significant decrease over time at $0.13 \mathrm{~cm} \mathrm{~d}^{-1}$ and $1.38 \mathrm{~cm} \mathrm{~d}^{-1}$, respectively. The difference of the trends indicated that the patterns of interaction between SW-GW were related to the areas with or without permafrost.

\section{3.3 Spatial patterns of SW-GW interactions}

We carried out FO-DTS temperature surveys at S1 and P2 in September 2016 (Fig. 5). The observed temperature revealed that stream warming occurred from 09:00 am until 16:00 pm and cooling occurred from 16:00 pm to 09:00 am, corresponding to the piezometer measurements. The temperature of the water column at P2 was lower than that at S2 because the depth of the water column at $\mathrm{P} 2$ was shallower than that at $\mathrm{S} 2$. The temperature changes at the bottom of surface water column varied less than $0.06{ }^{\circ} \mathrm{C}$ along the investigated stream reach.

An analysis on the strength of temperature anomalies $\operatorname{AT}\left(x_{i}\right)$ revealed a largely homogeneous temperature patterns in the streambed, with a temperature variability of up to $0.7^{\circ} \mathrm{C}$ at $\mathrm{S} 1$ (Fig. 6a). The common temperature variations are of $\pm 0.4{ }^{\circ} \mathrm{C}$ 
The Cryosphere Discuss., https://doi.org/10.5194/tc-2017-176

Manuscript under review for journal The Cryosphere

Discussion started: 5 September 2017

(c) Author(s) 2017. CC BY 4.0 License.

and around the spatial average. There were no distinct cold spots or high temperature variations (STDEV) along the cable at S1, indicating that there was no up-welling of groundwater. Two warm spots were identified without temporal persistence, probably as a result of shallow water depths blocked by rocks.

The strength of temperature anomalies $A_{T}\left(x_{i}\right)$ and their temporal standard deviations (STDEV) at P2 also showed homogeneous

5 temperature patterns in the streambed (Fig. 6b). The temperature difference to spatial mean was less than $0.25{ }^{\circ} \mathrm{C}$ and the STDEV was near $0{ }^{\circ} \mathrm{C}$. Some slight cold spots were identified in the temperature anomalies analysis. Because the influence of heat conduction and streambed topography has been identified up to $0.3{ }^{\circ} \mathrm{C}$ (Krause et al., 2011), while values of the temperature anomaly were with a ranged of -0.16 to $-0.25^{\circ} \mathrm{C}$. Thus, they were considered to be the uncertainty of the FO-DTS data interpretations rather than the influence of cold groundwater. As shown by the low STDEV, we found no anomalies

10 analogous to the colder up-welling groundwater in the observation reaches, possibly explaining the bypassing of regional groundwater due to preferential lateral flow or confining streambed structures beneath the zone of investigated (Krause et al., 2012).

\section{Discussion}

\subsection{Implications of SW-GW interaction in permafrost region}

15 The losing condition at all the observation sites and the less temperature anomalies demonstrated the low connectivity between the stream and the underlying aquifer. The changes in the relative connectivity between the stream and the underlying aquifer can influence interactions between SW-GW (Hatch et al., 2010). Permafrost can act as an impermeable layer that limits infiltration, storage, and connectivity with deeper regional flow. Then it can lead to a higher hydraulic head in the subpermafrost aquifer and lower hydraulic heads in the suprapermafrost aquifer (Woo, 2012). Later in the thawing period, as

20 the active layer thawing and groundwater table deepen beneath the stream, losing reaches in permafrost areas may become more disconnected between the surface water and groundwater. It should be noted that not all reaches in the YNG basin experienced losing conditions. Based on field observations, there were some instances of up-welling groundwater in the streambed near the lower boundary of permafrost. Result from isotopic tracer analyses performed by Li et al. (2016a, 2016b) in the other upper Heihe River sub-basins, indicated that water from the active layer accounted for 9-29\% of the total runoff

25 in July. Unfortunately, these reaches were not suitable for the FO-DTS observation because of the braided nature of the stream at these locations.

The trends of the thermal velocities demonstrated the SW-GW interactions tended to increase over time in the permafrost regions, associate with the deepening of the active layer thawing front. Carey et al. (2013) and Quinton and Baltzer (2013) suggested that the thickening active layer could lead to decreases in the bulk hydraulic conductivity $(K)$ and the hydraulic

30 gradient. Thus, the increasing SW-GW interaction in permafrost regions was caused mainly by increases in soil drainage (Walvoord et al., 2012), and the enhancement in suprapermafrost transmissivity due to the thickening countered by reductions 
The Cryosphere Discuss., https://doi.org/10.5194/tc-2017-176

Manuscript under review for journal The Cryosphere

Discussion started: 5 September 2017

(c) Author(s) 2017. CC BY 4.0 License.

in bulk $K$. The intensity of the SW-GW interaction in the area without permafrost fluctuated, but exhibited no trends in summer. This observation is consistent with studies using chemical and isotope analyses in a boreal catchment that indicated the thickening of the active layer can transmit more water through a lower hydraulic conductivity $(K)$ zone (Quinton and Baltzer, 2013; Koch et al., 2014). In summary, the heat tracing method can provide direct evidences for the increasing SW-GW

5 interactions that have been deduced through permafrost thaw modeling and chemical analyses.

Permafrost degradation has profound impacts on the hydrogeologic patterns, particularly the vertical and lateral flow paths that can transmit large groundwater fluxes (Carey et al., 2013; Wellman et al., 2013; Kurylyk et al., 2014). Groundwater contributes significantly to stream baseflow, with most groundwater flow presented as a suprapermafrost aquifer (Evans et al., 2015). Many groundwater modeling studies in permafrost regions have reported on the subsurface fluxes, including soil

10 drainage and recharge, and suprapermafrost flow. These studies have also shown that SW-GW exchanges can increase as the active layer thickening, with water uptake into suprapermafrost aquifer occurring when subpermafrost hydraulic heads rise (Bense et al., 2009, 2012; Evans et al., 2015; Ge et al., 2011). Although our observations did not demonstrate the impact of changes to the permafrost table, our results show increasing interactions between SW-GW with active layer thawing.

The approach we present provides the potential understanding of SW-GW interaction in permafrost regions for a broad range

15 of temporal and spatial scales by extending current knowledge from previous studies based on the point-in time or point-inspace measurements (Tyler et al., 2009). Our approach also supports the identification of spatial patterns and temporal distribution of the SW-GW interaction.

\subsection{Limitations and uncertainties in permafrost region}

The combination of FO-DTS derived streambed temperatures with HTE temperature gradients provides a powerful indicator 20 of SW-GW exchange controlled by the streambed. However, there are still limitations and uncertainties with this approach, particularly in permafrost regions.

\subsubsection{Limitations}

The harsh cold environment made very high demands of the measurement devices (on their accuracy, measurement range, and service life). Field measurements (Fig. 7) showed that the streambed temperatures in permafrost regions can fall below $0{ }^{\circ} \mathrm{C}$

25 in summer from July to September in 2015 , with air temperature differences between day and night up to $28^{\circ} \mathrm{C}$.

We installed FO-DTS at seven observation sites for temperature-depth variations in the study area, three of which failed because of equipment issues. Even in the available observation sites (e.g. S1), the sensor cannot exactly catch the signals giving rise abnormal data (green rectangles in Fig. 7). High discharge velocities are also a potential threat to the cable of the DTS measurement.

30 The physical and thermal properties of streambed limit the heat tracing method in permafrost regions. Physical and thermal parameters, such as porosity, sediment density, bulk thermal conductivity, and heat capacity, have been reported to be nearly 
The Cryosphere Discuss., https://doi.org/10.5194/tc-2017-176

Manuscript under review for journal The Cryosphere

Discussion started: 5 September 2017

(c) Author(s) 2017. CC BY 4.0 License.

independent of sediment texture and location (Rau et al., 2010). It is difficult to estimate accurate physical and thermal parameters, particularly in the roughness river course of the permafrost region, leading many heat tracing studies to use reference values obtained in the laboratory. For example, using the literature values of thermo-physical properties in the Monte Carlo analysis, there was nearly a 3-fold difference between the maximum and minimum Darcy velocity (McCullum et al., 5 2012).

The technological development of low-cost, accurate and reliable miniature temperature recorders has facilitated the measurement of stream temperatures (Webb. et al., 2008). Theoretically, the FO-DTS method has high temporal and spatial resolution and generally exceeds the traditional point-in time or point-in-space measurement (Tyler et al., 2009). However, the long-term temporal repeatability of DTS systems is unknown and is an area of continued design. The DTS system remains

10 very expensive for research applications and the environment for hydrologic applications is more complicated than that for industrial applications.

\subsubsection{Uncertainties}

To address the erroneous temporal spreading of advective velocities and significant anomalies induced by signal-processes techniques, such as Fourier transform and Dynamic Harmonic Regression (Hatch et al., 2006; Keery et al., 2007), our computer

15 program directly extracted sinusoidal temperature signals from noisy raw temperature records without filtering. As a result of the decline of energy with depth, some low energy oscillations became linear (i.e. without sinusoidal signal). There were 13 days without a sinusoidal signal at P2, 8 days at S2, and 6 days at S1, which correlates to $14.1 \%, 8.7 \%$, and $6.5 \%$, respectively, of the observation days. Thus, the cold environment in permafrost regions can result in many days lacking a sinusoidal signal at some depths. For example, the air temperature at 15 min interval at P2 showed that even in August, the air temperature fell

20 below the $0{ }^{\circ} \mathrm{C}$. The days without a sinusoidal signal occurred when extremely low temperatures were experienced at night or low temperatures were experienced during the daytime (Fig. 8).

System responses to sudden water flux transients may introduce errors. The temporal patterns of the changing thermal velocity can occur in association with short-term increases in channel discharge (Hatch et al., 2010). This was also noted in our observations at S1 (Fig. 9), where a high water level was followed by strong losing conditions. McCallum et al. (2012) concluded that rapid changes in hydraulic forcing (i.e., floods) can lead to erroneous fluxes because of a violation of the method assumptions. Furthermore, a reversal in the flux direction, as expected during flood events (e.g. the nature of the flood hydrograph as well as return flow to bank storage), complicates the system's thermal response. Thus, the use of heat tracing methods based on the assumption of harmonic temperature data will lead to potentially flawed flux estimates (Rau et al., 2015).

\section{Conclusions}

30 This study demonstrated the potential of heat tracing methods for studying the SW-GW interactions across the streambed in permafrost regions of the northern Tibetan Plateau. The 1-D HTE analytical heat tracing in the observation sites revealed the 
The Cryosphere Discuss., https://doi.org/10.5194/tc-2017-176

Manuscript under review for journal The Cryosphere

Discussion started: 5 September 2017

(c) Author(s) 2017. CC BY 4.0 License.

increasing SW-GW interaction induced by active layer thawing. The SW-GW interaction tended to increase with time in the areas with permafrost, occurring in association with the deepening of active layer thawing. As the active layer thawing and groundwater table becomes deeper beneath the stream later in thawing periods, losing reaches in permafrost areas may become more disconnected. Our results indicate that the heat tracing method can offer strong evidence for the increasing SW-GW 5 interactions induced by permafrost thaw.

Although the FO-DTS monitoring identified no up-welling groundwater in the observation area, when combined with 1-D HTE analytical analysis, the combined methods proved to be a useful indicator for the discrimination of temporal and spatial patterns of SW-GW interactions. By using the comparative 1-D HTE analytical heat tracing method and FO-DTS observed temperature anomalies, this study offers a validated strategy for optimizing the experimental design in a permafrost region

10 with limited information of streambed structure and physical properties.

Our approach has been validated for SW-GW interactions of summer streams in permafrost regions, with the active layer in thawing periods. Future work should focus on testing the application of the present approach and adapting it for complicated streambed environments in permafrost regions, including areas with or without permafrost and/or talik zones.

\section{Acknowledgements}

15 This work is supported by the National Natural Science Foundation of China (91325202; 41501063, 41671067), Fundamental Research Funds for the Central Universities (lzujbky-2017-40).

\section{Competing interests}

The authors declare that they have no conflict of interest

\section{References}

20 Abbott, B. W. and Jones, J. B.: Permafrost collapse alters soil carbon stocks, respiration, $\mathrm{CH}_{4}$, and $\mathrm{N}_{2} \mathrm{O}$ in upland tundra, Glob. Change Biol., 21, 4570-4587, doi:10.1111/gcb.13069, 2015.

Bense, V. F., Ferguson, G., and Kooi, H.: Evolution of shallow groundwater flow systems in areas of degrading permafrost, Geophys. Res. Lett., 36, doi:10.1029/2009g1039225, 2009.

Bense, V. F., Kooi, H., Ferguson, G., and Read, T.: Permafrost degradation as a control on hydrogeological regime shifts in a warming climate, J. Geophys. Res., 117, F03036, doi:10.1029/2011jf002143, 2012.

Bi, Y., Xie, H., Huang, C., and Ke, C.: Snow cover variations and controlling factors at Upper Heihe River Basin, Northwestern China, Remote Sens., 7, 6741-6762, doi:10.3390/rs70606741, 2015. 
The Cryosphere Discuss., https://doi.org/10.5194/tc-2017-176

Manuscript under review for journal The Cryosphere

Discussion started: 5 September 2017

(c) Author(s) 2017. CC BY 4.0 License.

Brown, J., Hinkel, K., and Nelson, F.: The circumpolar active layer monitoring (calm) program: Research designs and initial results 1, Polar Geogr., 24, 166-258, 10.1080/10889370009377698, 2000.

Carey, S. K., Boucher, J. L., and Duarte, C. M.: Inferring groundwater contributions and pathways to streamflow during snowmelt over multiple years in a discontinuous permafrost subarctic environment (Yukon, Canada), Hydrogeol. J., 21, 67-77, doi:10.1007/s10040-012-0920-9, 2013.

Chasmer, L. and Hopkinson, C.: Threshold loss of discontinuous permafrost and landscape evolution, Glob. Change Biol., doi:10.1111/gcb.13537, 2016.

Cheng, G. and Jin, H.: Permafrost and groundwater on the Qinghai-Tibet Plateau and in northeast China, Hydrogeol. J., 21, 523, doi:10.1007/s10040-012-0927-2, 2013.

10 Cheng, G., Li, X., Zhao, W., Xu, Z., Feng, Q., Xiao, S., and Xiao, H.: Integrated study of the water-ecosystem-economy in the Heihe River Basin, Natl. Sci. Rev., 1, 413-428, doi:10.1093/nsr/nwu017, 2014.

Constantz, J.: Heat as a tracer to determine streambed water exchanges, Water Resour. Res., 44, W00D10, doi:10.1029/2008wr006996, 2008.

Constantz, J., Eddy-Miller, C. A., Wheeler, J. D., and Essaid, H. I.: Streambed exchanges along tributary streams in humid watersheds, Water Resour. Res., 49, 2197-2204, doi:10.1002/wrcr.20194, 2013.

Cuo, L., Zhang, Y., Gao, Y., Hao, Z., and Cairang, L.: The impacts of climate change and land cover/use transition on the hydrology in the upper Yellow River Basin, China, J. Hydrol., 502, 37-52, doi:10.1016/j.jhydrol.2013.08.003, 2013.

Evans, S. G., Ge, S., and Liang, S.: Analysis of groundwater flow in mountainous, headwater catchments with permafrost, Water Resour. Res., 51, 9564-9576, doi:10.1002/2015wr017732, 2015.

20 Gao, T., Zhang, T., Cao, L., Kang, S., and Sillanpää, M.: Reduced winter runoff in a mountainous permafrost region in the northern Tibetan Plateau, Cold Reg. Sci. Technol., 126, 36-43, doi:10.1016/j.coldregions.2016.03.007, 2016.

Ge, S., McKenzie, J., Voss, C., and Wu, Q.: Exchange of groundwater and surface-water mediated by permafrost response to seasonal and long term air temperature variation, Geophys. Res. Lett., 38, L14402, doi:10.1029/2011g1047911, 2011.

Gordon, R. P., Lautz, L. K., Briggs, M. A., and McKenzie, J. M.: Automated calculation of vertical pore-water flux from field temperature time series using the VFLUX method and computer program, J. Hydrol., 420-421, 142-158, doi:10.1016/j.jhydrol.2011.11.053 2012.

Goto, S., Yamano, M., and Kinoshita, M.: Thermal response of sediment with vertical fluid flow to periodic temperature variation at the surface, J. Geophys. Res., 110, B01106, doi:10.1029/2004JB003419, 2005.

Hatch, C. E., Fisher, A. T., Revenaugh, J. S., Constantz, J., and Ruehl, C.: Quantifying surface water-groundwater interactions using time series analysis of streambed thermal records: Method development, Water Resour. Res., 42, W10410, doi:10.1029/2005wr004787, 2006.

Hatch, C. E., Fisher, A. T., Ruehl, C. R., and Stemler, G.: Spatial and temporal variations in streambed hydraulic conductivity quantified with time-series thermal methods, J. Hydrol., 389, 276-288, doi:10.1016/j.jhydrol.2010.05.046, 2010. 
The Cryosphere Discuss., https://doi.org/10.5194/tc-2017-176

Manuscript under review for journal The Cryosphere

Discussion started: 5 September 2017

(c) Author(s) 2017. CC BY 4.0 License.

Huai, B., Li, Z., Sun, M., Zhou, P., and Xiao, Y.: RS analysis of glaciers change in the Heihe River Basin in the last 50 years, Acta Geogr Sin., 69, 365-376, doi:10.11821/dlxb201403008, 2014.

Irvine, D. J., Briggs, M. A., Lautz, L. K., Gordon, R. P., McKenzie, J. M., and Cartwright, I.: Using Diurnal Temperature Signals to Infer Vertical Groundwater-Surface Water Exchange, Groundwater, 55, 10-26, doi:10.1111/gwat.12459, 2017.

Keery, J., Binley, A., Crook, N., and Smith, J. W. N.: Temporal and spatial variability of groundwater-surface water fluxes: Development and application of an analytical method using temperature time series, J. Hydrol., 336, 1-16, doi:10.1016/j.jhydrol.2006.12.003, 2007.

Koch, J. C., Kikuchi, C. P., Wickland, K. P., and Schuster, P.: Runoff sources and flow paths in a partially burned, upland boreal catchment underlain by permafrost, Water Resour. Res., 50, 8141-8158, doi:10.1002/2014wr015586, 2014.

Krause, S., Hannah, D., and Blume, T.: Heat transport patterns at pool-riffle sequences of an UK lowland stream, Ecohydrol., 4, 549-563, doi:10.1002/eco.199, 2011.

Krause, S., Blume, T., and Cassidy, N.: Investigating patterns and controls of groundwater up-welling in a lowland river by combining Fibre-optic Distributed Temperature Sensing with observations of vertical hydraulic gradients, Hydrol. Earth Syst. Sci., 16, 1775-1792, doi:10.5194/hess-16-1775-2012, 2012.

Kurylyk, B. L., MacQuarrie, K. T. B., and McKenzie, J. M.: Climate change impacts on groundwater and soil temperatures in cold and temperate regions: Implications, mathematical theory, and emerging simulation tools, Earth Sci. Rev., 138, 313-334, doi:10.1016/j.earscirev.2014.06.006, 2014.

Lauer, F., Frede, H.-G., and Breuer, L.: Uncertainty assessment of quantifying spatially concentrated groundwater discharge to small streams by distributed temperature sensing, Water Resour. Res., 49, 400-407, doi:10.1029/2012wr012537, 2013.

Lautz, L. K.: Observing temporal patterns of vertical flux through streambed sediments using time-series analysis of temperature records, J. Hydrol., 464-465, 199-215, doi:10.1016/j.jhydrol.2012.07.006, 2012.

Liu, C., Liu, J., Wang, X.-S., and Zheng, C.: Analysis of groundwater-lake interaction by distributed temperature sensing in Badain Jaran Desert, Northwest China, Hydrol. Process., 30, 1330-1341, doi:10.1002/hyp.10705, 2016.

Liu, J. S., Xie, J., Gong, T. L., Wang, H., and Xie, Y. H.: Impacts of winter warming and permafrost degradation on water variability, upper Lhasa River, Tibet, Quat. Int., 244, 178-184, doi:10.1016/j.quaint.2010.12.018, 2011.

McCallum, A. M., Andersen, M. S., Rau, G. C., and Acworth, R. I.: A 1-D analytical method for estimating surface watergroundwater interactions and effective thermal diffusivity using temperature time series, Water Resour. Res., 48, W11532, doi:10.1029/2012wr012007, 2012.

Quinton, W., and Baltzer, J.: The active-layer hydrology of a peat plateau with thawing permafrost (Scotty Creek, Canada), Hydrogeol. J., 21, 201-220, doi:10.1007/s10040-012-0935-2, 2013. 
The Cryosphere Discuss., https://doi.org/10.5194/tc-2017-176

Manuscript under review for journal The Cryosphere

Discussion started: 5 September 2017

(c) Author(s) 2017. CC BY 4.0 License.

Rau, G. C., Andersen, M. S., McCallum, A. M., and Acworth, R. I.: Analytical methods that use natural heat as a tracer to quantify surface water-groundwater exchange, evaluated using field temperature records, Hydrogeol. J., 18, 1093-1110, doi:10.1007/s10040-010-0586-0, 2010.

Rau, G. C., Andersen, M. S., McCallum, A. M., Roshan, H., and Acworth, R. I.: Heat as a tracer to quantify water flow in near-surface sediments, Earth Sci. Rev., 129, 40-58, doi:10.1016/j.earscirev.2013.10.015, 2014.

Rau, G. C., Cuthbert, M. O., McCallum, A. M., Halloran, L. J. S., and Andersen, M. S.: Assessing the accuracy of 1-D analytical heat tracing for estimating near-surface sediment thermal diffusivity and water flux under transient conditions, J. Geophys. Res. Earth Surf., 120, 1551-1573, doi:10.1002/2015jf003466, 2015.

Rose, L., Krause, S., and Cassidy, N. J.: Capabilities and limitations of tracing spatial temperature patterns by fiber-optic distributed temperature sensing, Water Resour. Res., 49, 1741-1745, doi:10.1002/wrcr.20144, 2013.

Selker, J. S., Thevenaz, L., Huwald, H., Mallet, A., Luxemburg, W., de Giesen, N. v., Stejskal, M., Zeman, J., Westhoff, M., and Parlange, M. B.: Distributed fiber-optic temperature sensing for hydrologic systems, Water Resour. Res., 42, W12202, doi:10.1029/2006wr005326, 2006.

Stallman, R.W.: Steady one-dimensional fluid flow in a semi-infinite porous medium with sinusoidal surface temperature, J. Geophys. Res., 70, 2821-2827, doi:10.1029/JZ070i012p02821, 1965.

Suzuki, S.: Percolation measurements based on heat flow through soil with special reference to paddy fields, J. Geophys. Res., 65, 2883-2885, doi:10.1029/JZ065i009p02883, 1960.

Tyler, S. W., Selker, J. S., Hausner, M. B., Hatch, C. E., Torgersen, T., Thodal, C. E., and Schladow, S. G.: Environmental temperature sensing using Raman spectra DTS fiber-optic methods, Water Resour. Res., 45, W00D23, doi:10.1029/2008wr007052, 2009.

Walvoord, M. A., Voss, C. I., and Wellman, T. P.: Influence of permafrost distribution on groundwater flow in the context of climate-driven permafrost thaw: Example from Yukon Flats Basin, Alaska, United States, Water Resour. Res., 48, W07524, doi:10.1029/2011wr011595, 2012.

Walvoord, M. A. and Kurylyk, B. L.: Hydrologic Impacts of Thawing Permafrost-A Review, Vadose Zone J., 15, doi:10.2136/vzj2016.01.0010, 2016.

Wang, Q., Zhang, T., Wu, J., PENG, X.-q., ZHONG, X.-y., Mou, C., Wang, K., Wu, Q., and Cheng, G.: Investigation on Permafrost Distribution over the Upper Reaches of the Heihe River in the Qilian Mountains, J. Glaciol. Geocryol., 35, 19-29, doi:10.7522/j.issn.1000-0240.2013.0003, 2013.

Wang, T.: 1:4000000 Map of the Glaciers, Frozen Ground and Deserts in China, Science Press, Beijing, 2006.

30 Wellman, T. P., Voss, C. I., and Walvoord, M. A.: Impacts of climate, lake size, and supra- and sub-permafrost groundwater flow on lake-talik evolution, Yukon Flats, Alaska (USA), Hydrogeol. J., 21, 281-298, doi:10.1007/s10040-012-0941$4,2013$.

Woo, M.-k.: Permafrost hydrology, Springer Science \& Business Media, Berlin, Germany, doi:10.1007/978-3-642-23462-0, 2012. 
The Cryosphere Discuss., https://doi.org/10.5194/tc-2017-176

Manuscript under review for journal The Cryosphere

Discussion started: 5 September 2017

(c) Author(s) 2017. CC BY 4.0 License.

(c) (i)

Webb, B. W., Hannah, D. M., Moore, R. D., Brown, L. E., and Nobilis, F.: Recent advances in stream and river temperature research, Hydrol. Process., 22, 902-918, 10.1002/hyp.6994, 2008.

Yao, T., Thompson, L., Yang, W., Yu, W., Gao, Y., Guo, X., Yang, X., Duan, K., Zhao, H., Xu, B., Pu, J., Lu, A., Xiang, Y., Kattel, D. B., and Joswiak, D.: Different glacier status with atmospheric circulations in Tibetan Plateau and surroundings, Nat. Clim. Change, 2, 663-667, doi:10.1038/nclimate1580, 2012.

Ye, B. S., Yang, D. Q., Zhang, Z. L., and Kane, D. L.: Variation of hydrological regime with permafrost coverage over Lena Basin in Siberia, J. Geophys. Res.-Atmos., 114, D07102, doi:10.1029/2008jd010537, 2009.

Li, Z., Qi, F., Song, Y., Wang, Q. J., Yang, J., Li, Y., Li, J., and Guo, X.: Stable isotope composition of precipitation in the south and north slopes of Wushaoling Mountain, northwestern China, Atmos. Res., 182, 87-101, doi:10.1016/j.atmosres.2016.07.023, 2016a.

Li Z., Qi, F., Wang, Q. J., Song, Y., Cheng, A., and Li, J.: Contribution from frozen soil meltwater to runoff in an in-land river basin under water scarcity by isotopic tracing in northwestern China, Glob. Planet. Change, 136, 41-51, doi:10.1016/j.gloplacha.2015.12.002, 2016b. 
The Cryosphere Discuss., https://doi.org/10.5194/tc-2017-176

Manuscript under review for journal The Cryosphere

Discussion started: 5 September 2017

(c) Author(s) 2017. CC BY 4.0 License.

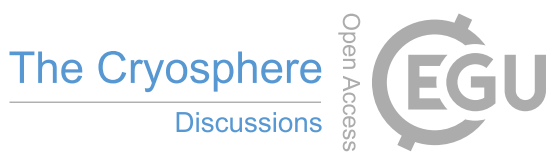
(c) (i)

\section{Figures}
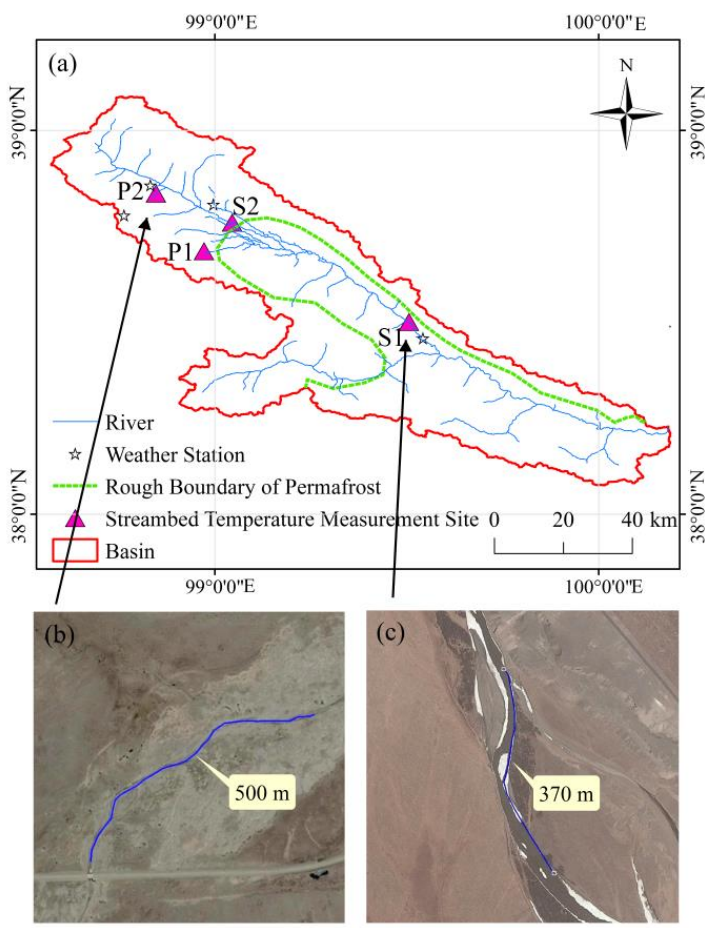

Figure 1. (a) Yeniugou Basin in the northern Tibetan Plateau and the hydrometeorological measurement sites (S1, S2, P1, and P2), (b) FO-DTS measurement at P2, and (c) FO-DTS measurement at S1. 
The Cryosphere Discuss., https://doi.org/10.5194/tc-2017-176

Manuscript under review for journal The Cryosphere

Discussion started: 5 September 2017

(c) Author(s) 2017. CC BY 4.0 License.
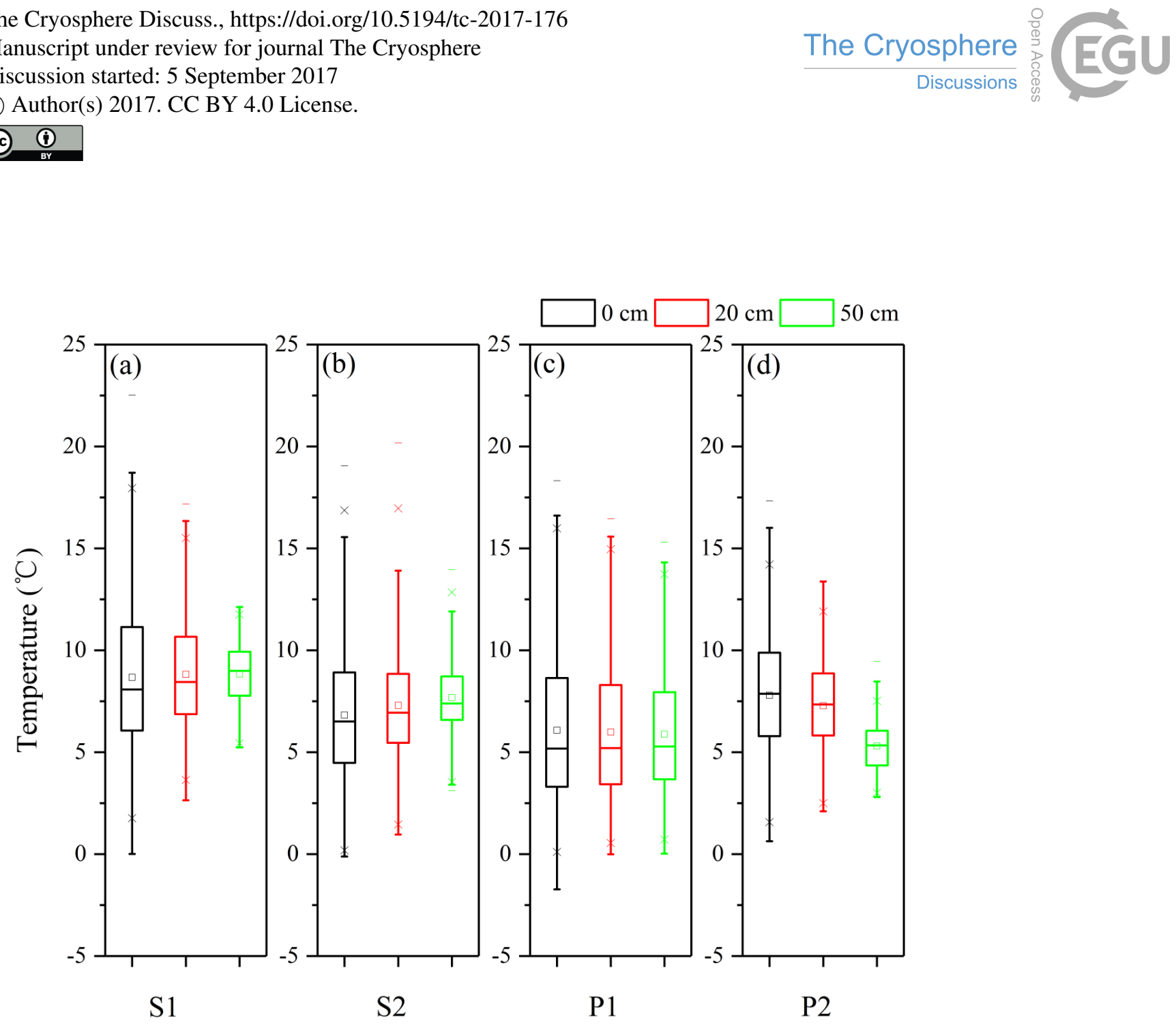

Figure 2. Boxplot of streambed temperatures at (a) S1, (b) S2, (c) P1, and (d) P2 during July to September in 2015. 
The Cryosphere Discuss., https://doi.org/10.5194/tc-2017-176

Manuscript under review for journal The Cryosphere

Discussion started: 5 September 2017

(c) Author(s) 2017. CC BY 4.0 License.

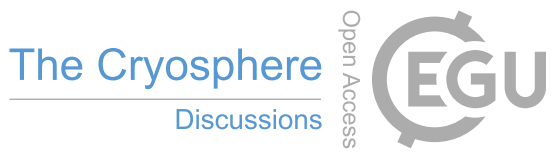

(c) (i)

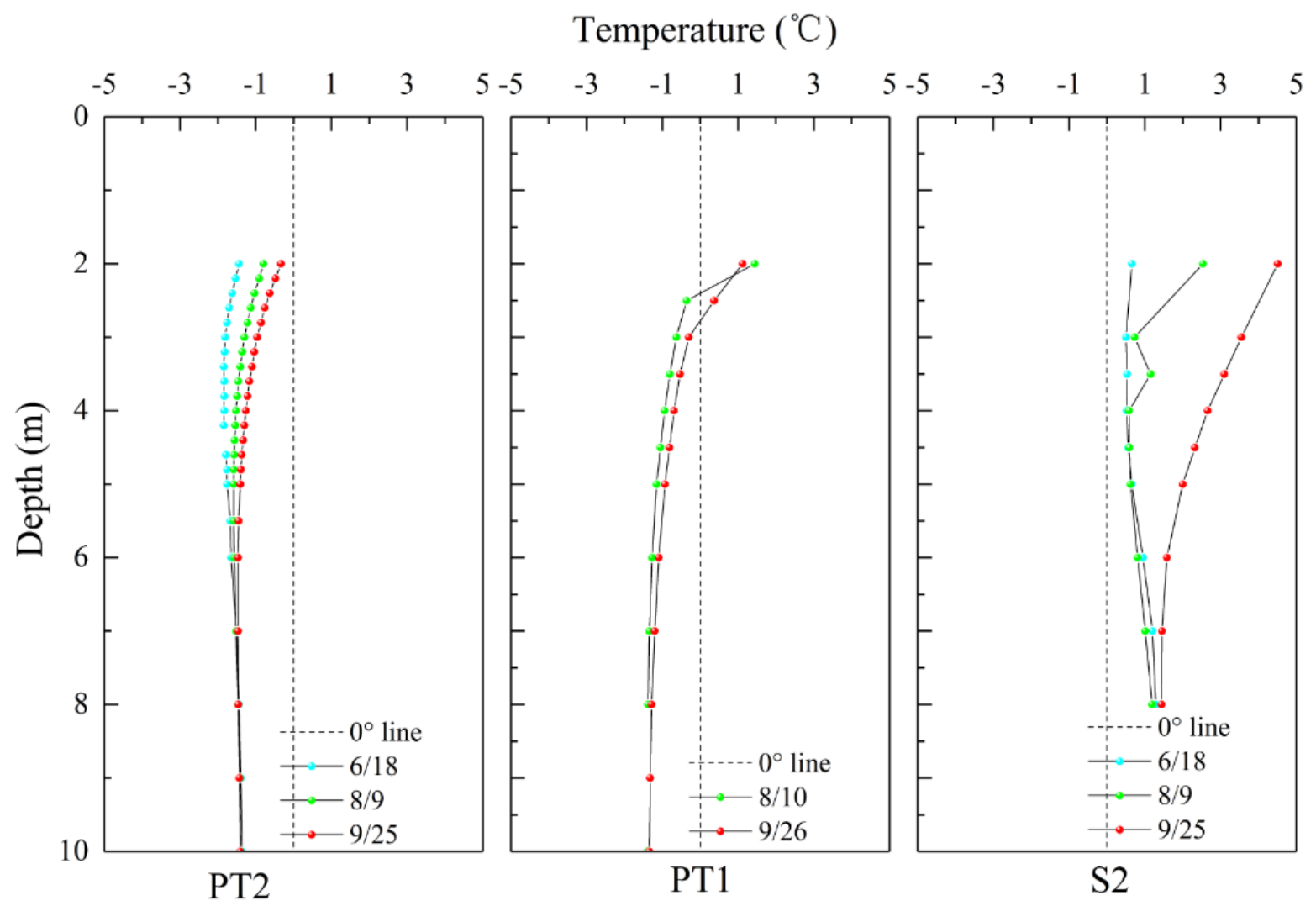

Figure 3. Borehole temperatures near the streambed temperature observation sites (P1, P2, and S2) on 18 June, 9 August, and 25 September in 2015. 
The Cryosphere Discuss., https://doi.org/10.5194/tc-2017-176

Manuscript under review for journal The Cryosphere

Discussion started: 5 September 2017

(c) Author(s) 2017. CC BY 4.0 License.
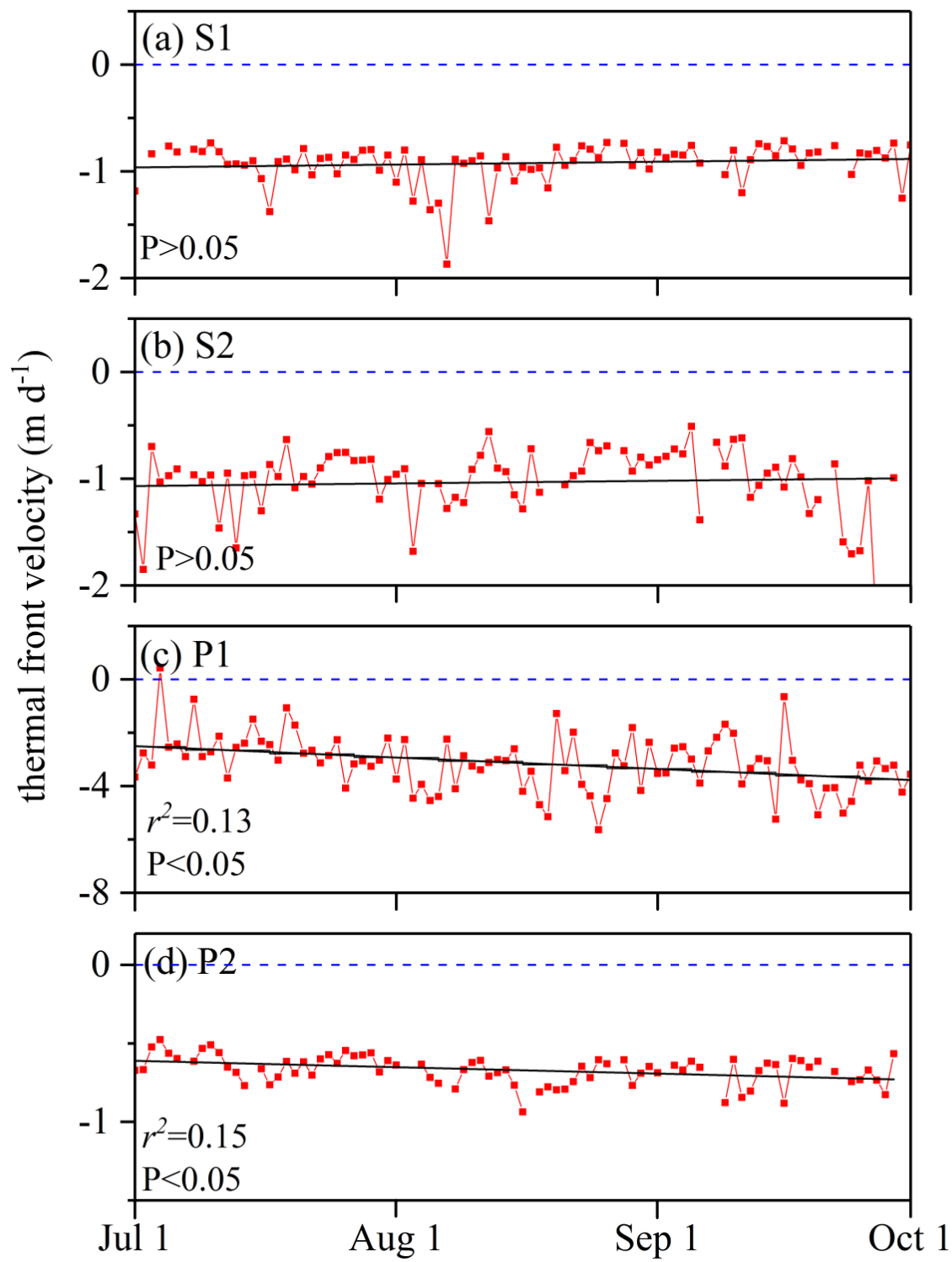

Figure 4. Thermal front velocities and the trends in Yeniugou stream in the northern Tibetan Plateau from July to September in 2015 at (a) S1, (b) S2, (c) P1, and (d) P2. (the dashed blue lines represent the thermal front velocity is zero; the fine black lines mean the fit linear) 
The Cryosphere Discuss., https://doi.org/10.5194/tc-2017-176

Manuscript under review for journal The Cryosphere

Discussion started: 5 September 2017

(c) Author(s) 2017. CC BY 4.0 License.

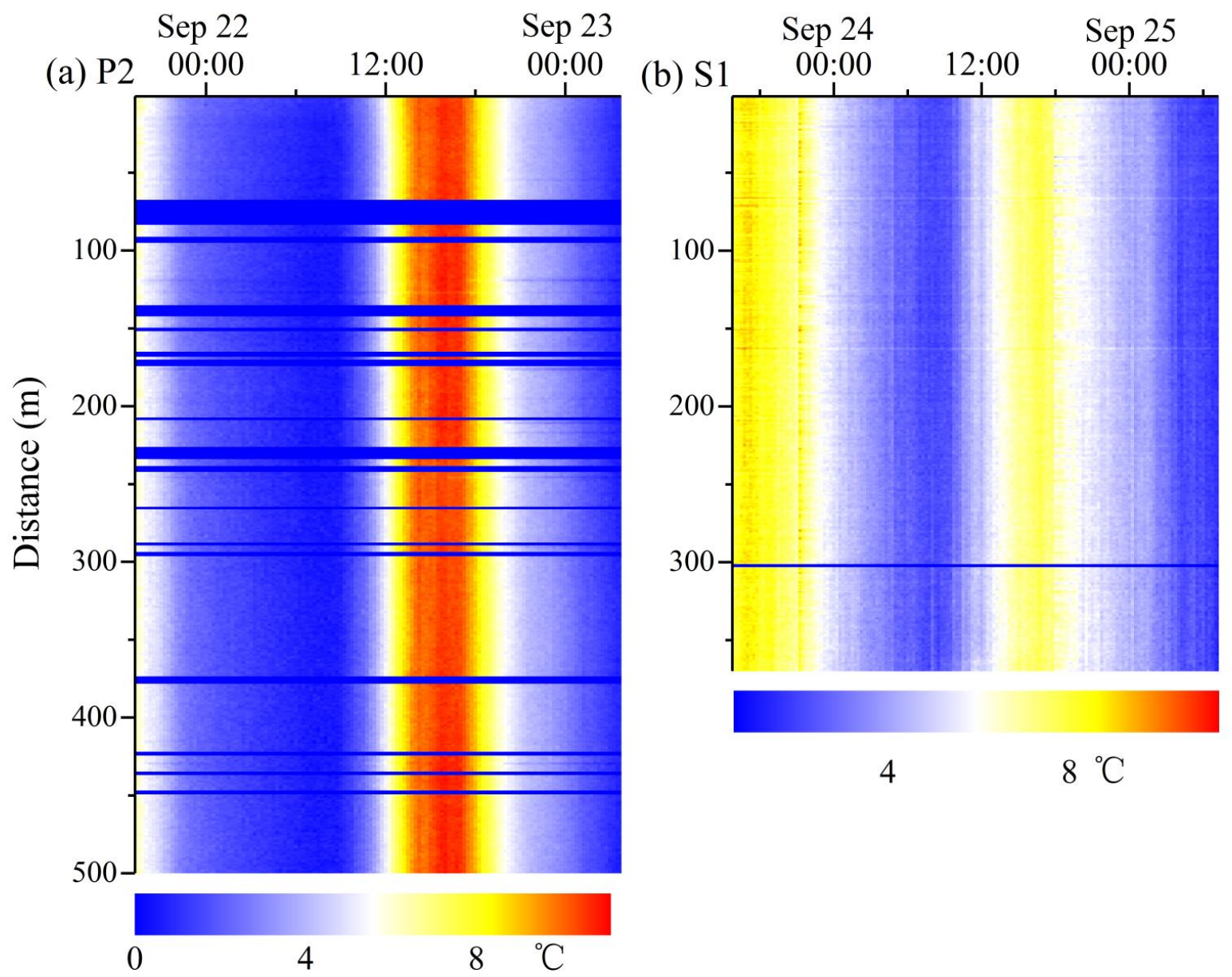

Figure 5. Riverbed temperatures measured by FO-DTS at (a) P2 (from 19:00 Sep 21 to 03:00 Sep 23, 2015) and (b) S1 (from 15:00 Sep 23 to 07:00 Sep 25, 2015). 
The Cryosphere Discuss., https://doi.org/10.5194/tc-2017-176

Manuscript under review for journal The Cryosphere

Discussion started: 5 September 2017

(c) Author(s) 2017. CC BY 4.0 License.

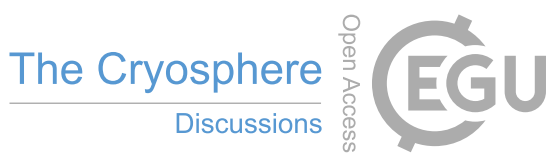

(c) (i)

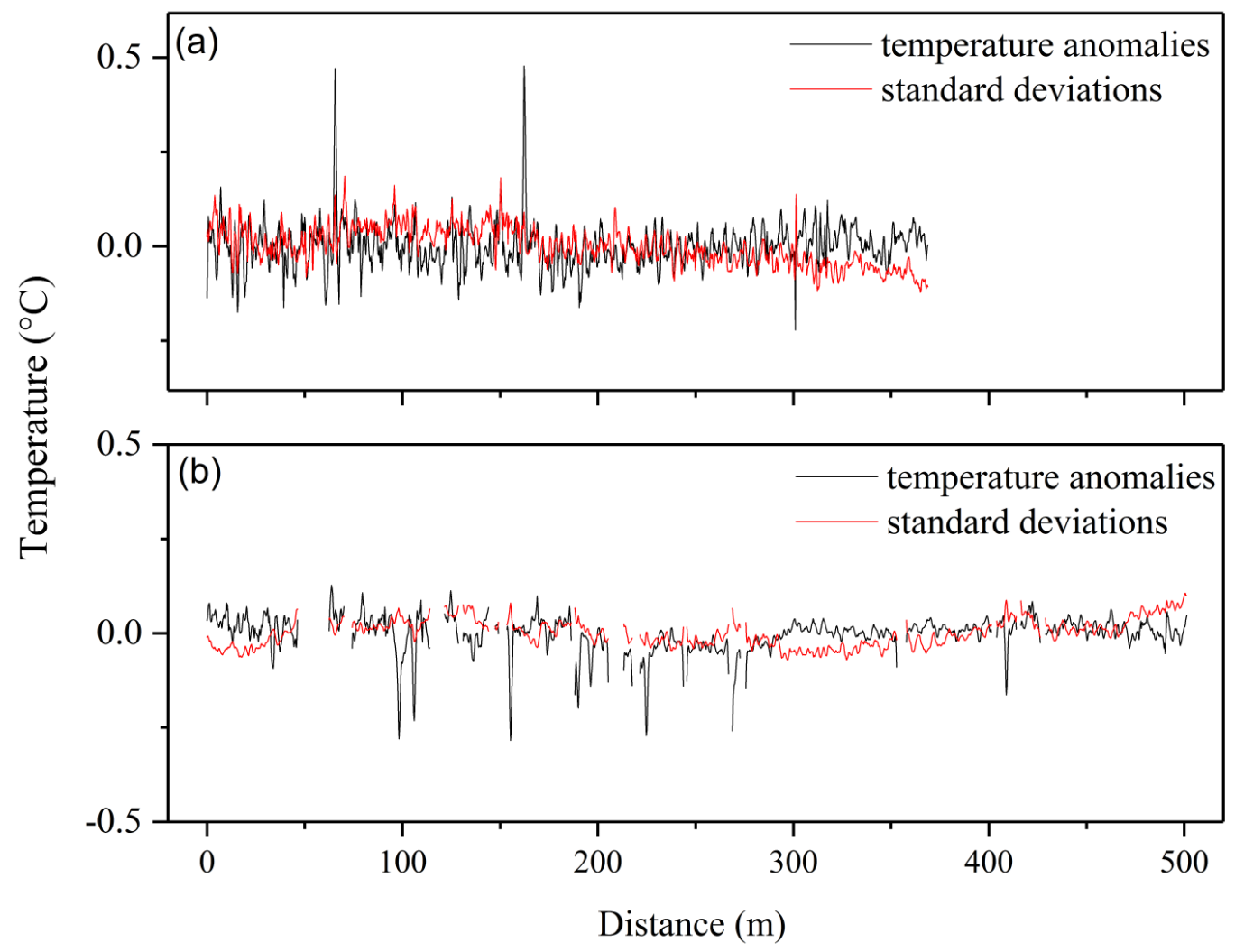

Figure 6. FO-DTS monitored temperature variability along the cable at S1 (a) and P2 (b). 
The Cryosphere Discuss., https://doi.org/10.5194/tc-2017-176

Manuscript under review for journal The Cryosphere

Discussion started: 5 September 2017

(c) Author(s) 2017. CC BY 4.0 License.

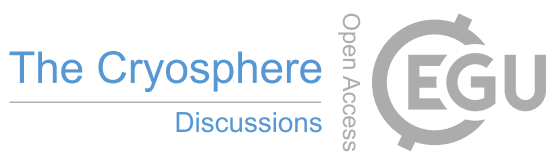

(c) (i)

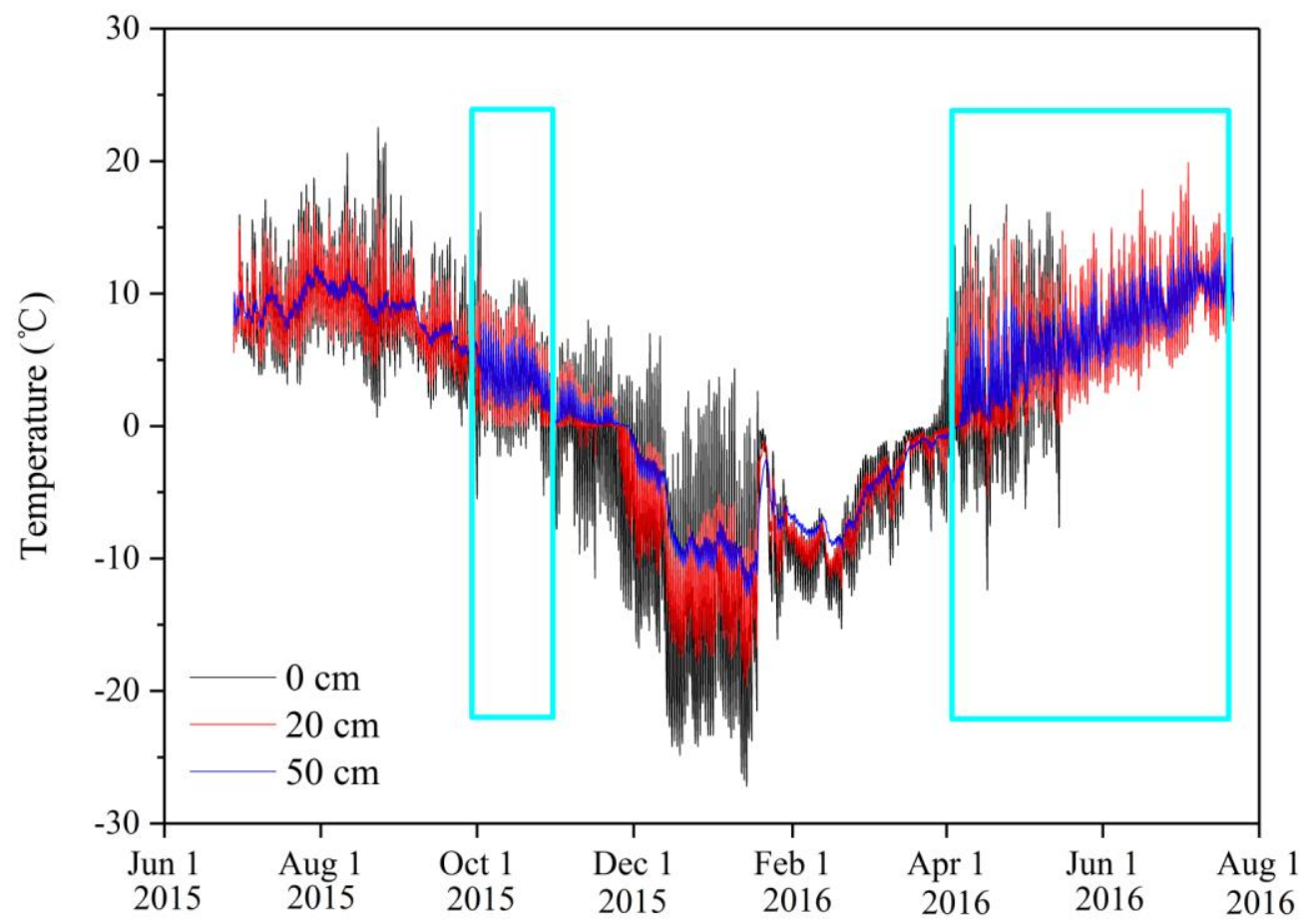

Figure 7. Time series of S1 stream temperatures at depths of $0 \mathrm{~cm}, 20 \mathrm{~cm}$ and $50 \mathrm{~cm}$ from July 2015 to July 2016 . The green boxes mean the abnormal data in the measure period. 
The Cryosphere Discuss., https://doi.org/10.5194/tc-2017-176

Manuscript under review for journal The Cryosphere

Discussion started: 5 September 2017

(c) Author(s) 2017. CC BY 4.0 License.
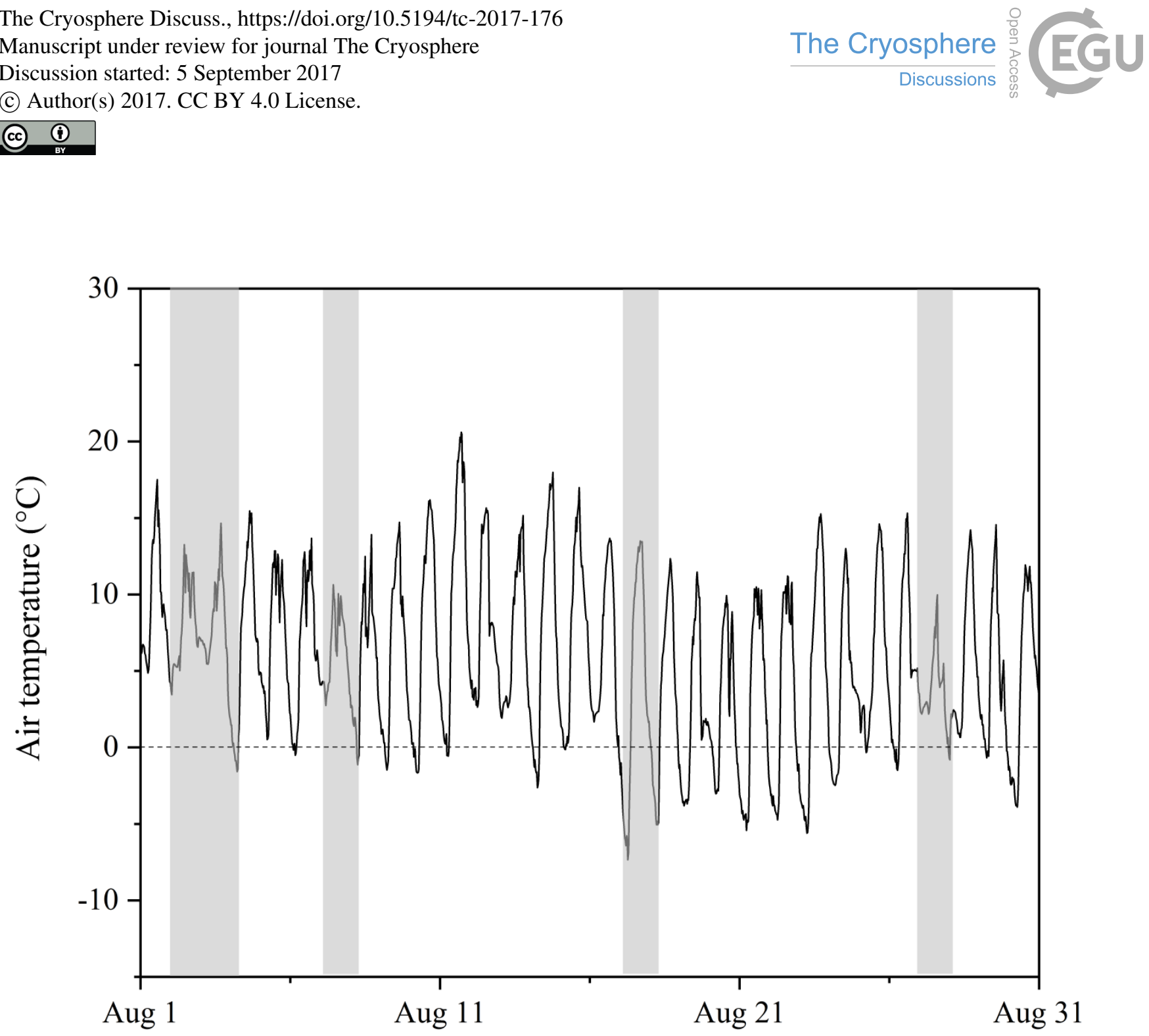

Figure 8. Air temperatures at $P 2$ in August 2015. Grey rectangle indicates days without sinusoidal signal at $50 \mathrm{~cm}$ depth. 
The Cryosphere Discuss., https://doi.org/10.5194/tc-2017-176

Manuscript under review for journal The Cryosphere

Discussion started: 5 September 2017

(c) Author(s) 2017. CC BY 4.0 License.

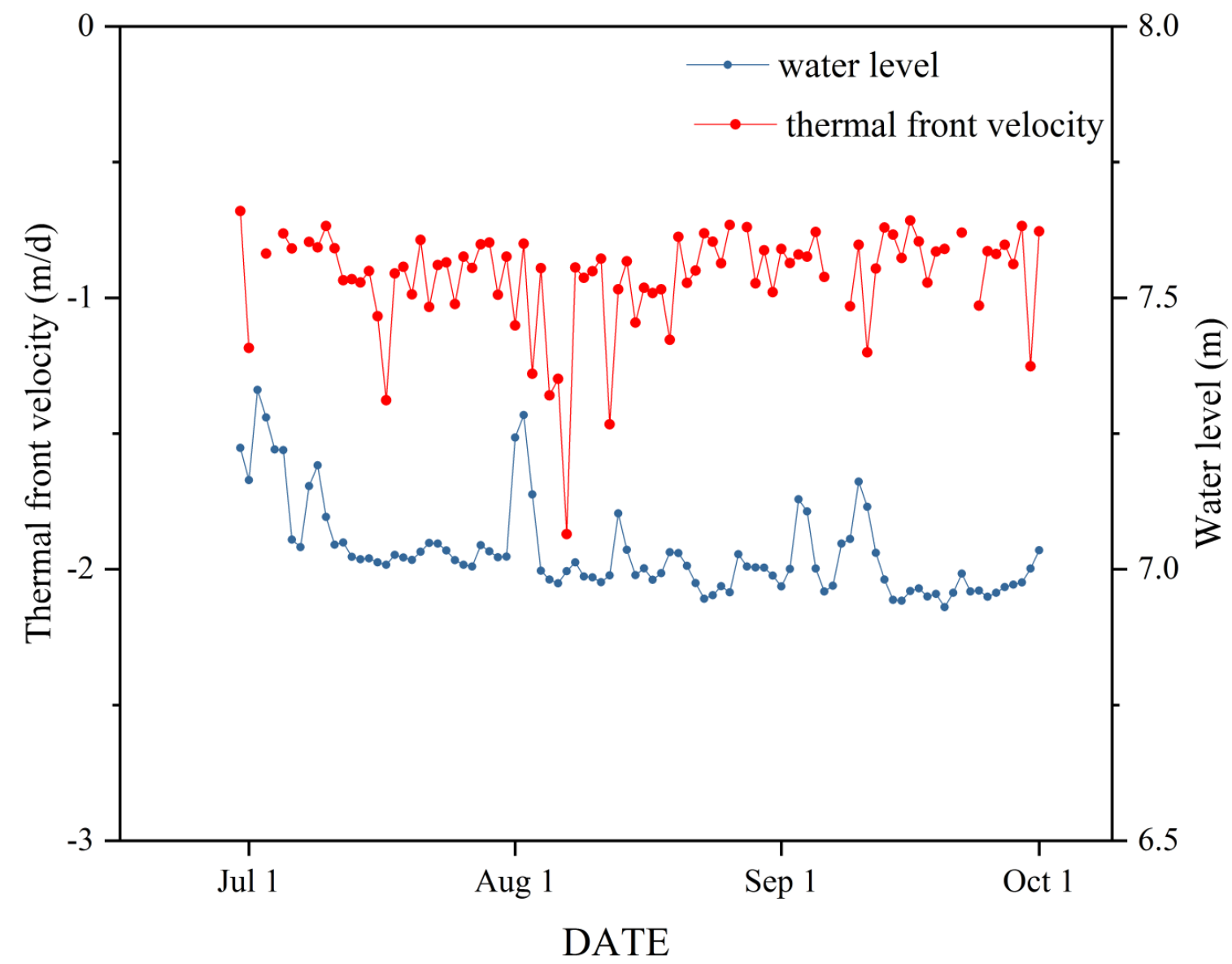

Figure 9. Time series of thermal front velocity and water level changes at S1 from July to September in 2015. 